\title{
The Bichordites ichnofabric in the Pleistocene ocean current-generated sand ridge complex
}

\author{
Masakazu NARA
}

Department of Natural Sciences, Kochi University, 780-8577 Kochi, Japan; nara@kochi-u.ac.jp

Nara, M. 2014. The Bichordites ichnofabric in the Pleistocene ocean current-generated sands ridge complex. [Ichnofábrica de Bichordites del complejo de barras arenosas generadas por corrientes oceánicas del Pleistoceno]. Spanish Journal of Palaeontology, 29 (2), 191-202.

\begin{abstract}
The ichnofabric characterised by Bichordites monastiriensis, a fossil burrow of the echinocardiid spatangoid echinoid, is first reported from the large-scale subaqueous dune (sand wave) deposits of the ocean current-generated shelf sand ridge complex of the middle Pleistocene Ichijiku Formation of the Boso penisula, Japan. It consists of dominant B. monastiriensis and associated Alcyonidiopsis, large Macaronichnus, Piscichnus, Scolicia, Skolithos and unnamed escape structures. Similar Bichordites-dominant ichnofabrics have been reported from Neogene to Quaternary sand wave deposits formed by various agents (such as tidal currents, storm-induced currents, or fair-weather wave-generated currents) whose depositional environments range from the deep sea floor to the shallow shelf. Although sand wave systems are commonly characterised by rapid sedimentation and highly shifting substrates, preventing colonisation by most benthic animals, rapid burrowers such as the echinocardiids were likely able to inhabit these regions regardless of the dominant depositional agents or the water depths of the habitats. The fossil record of Bichordites dates back to the Oligocene, although the trace fossil became particularly
\end{abstract}

\section{RESUMEN}

La icnofábrica caracterizada por Bichordites monastiriensis, una traza fósil atribuida a espatangoideos del género Echinocardium, se describe por primera vez en los depósitos de dunas subacuáticas de gran escala (ondas de arena) del complejo de barras arenosas de plataforma generadas por corrientes oceánicas del Pleistoceno medio de la Formación Ichijiku (península de Boso, Japón). Esta icnofábrica, dominada por la icnoespecie $B$. monastirienses, también presenta Alcyonidiopsis, grandes Macaronichnus, Piscichnus, Scolicia, Skolithos y estructuras de escape sin nominar. Se han registrado icnofábricas dominadas por Bichordites similares a las descritas aquí desde el Neógeno al Cuaternario en depósitos de barras de arena formados por diversos agentes (ya sean mareas, o corrientes inducidas por tormentas o por buen tiempo) y en ambientes deposicionales que varían de fondos marinos profundos a plataformas someras. Aunque los sistemas de barras arenosas están comúnmente caracterizados por una rápida sedimentación y por sustratos con gran movilidad, que evitan la colonización de la mayoría de animales bentónicos, bioturbadores rápidos como los equinocárdidos serían capaces de habitar en estas regiones, 
common in the Miocene and the known tracemakers (i.e., the echinocardiids and the maretiids) appeared in the Eocene. Moreover, these tracemakers now exhibit global distributions; therefore the ichnofabric described here may be used as an indicator of highly shifting substrates, such as those found in sand wave systems, in the Cenozoic.

Keywords: Bichordites monastiriensis ichnofabric, shifting substrates, palaeoenvironmental indicator, Ichijiku Formation, Japan. independientemente de los agentes deposicionales y de la profundidad. El registro fósil del icnogénero Bichordites se remonta al Oligoceno, aunque es especialmente abundante durante el Neógeno y sus productores (equinocárdidos y marétidos) aparecen en el Eoceno. Por otra parte, hoy en día estos equínidos bioturbadores presentan una distribución global; por lo tanto, la icnofábrica aquí descrita podría usarse como un indicador de sustratos con gran movilidad, tales como los que se encuentran en los sistemas de barras arenosas del Cenozoico.

Palabras clave: Icnofábrica de Bichordites monastiriensis, sustratos móviles, indicador paleoambiental, Formación Ichijiku, Japón.

\section{INTRODUCTION}

An ichnofabric characterised by Bichordites monastiriensis Plaziat and Mahmoudi, 1988, which has been interpreted as a burrow of the Echinocardium group spatangoids (Plaziat \& Mahmoudi, 1988; Uchman \& Krenmayr, 1995), has been found in the large-scale subaqueous dune (sand wave) deposits of an ocean current-generated shelf sand ridge complex of the middle Pleistocene Ichijiku Formation (Nakayama \& Masuda, 1989; Horikawa \& Ito, 2004; Sato et al., 2006) on the Boso penisula of central Japan. The ichnofabric consists of dominant B. monastiriensis and associated trace fossils, including Alcyonidiopsis, Macaronichnus, Piscichnus, Scolicia, Skolithos, and unnamed escape structures.

Similar ichnofabrics characterised by Bichordites and occurring in trough or planar cross-bedded sandstones have also been reported from Neogene to Quaternary sand wave deposits (e.g., D'Alessandro \& Massari, 1997; D'Alessandro et al., 2004; Gibert \& Goldring, 2007, 2008; Aguirre et al., 2010). For example, D'Alessandro \& Massari (1997) reported a similar ichnofabric characterised by the dense occurrence of Bichordites from large-scale clinoforms of the Pleistocene deposits of Salento, Italy. The development of migrating sand waves on these clinoforms has been attributed primarily to episodic storm-related currents (D'Alessandro \& Massari, 1997). Meniscate trace fossils of Echinocardium cordatum, which were comparable with Bichordites, were also found from Italian Pliocene-Pleistocene sand wave deposits, which consist primarily of large-scale cross bedding, up to 2.5 $m$ in thickness (Colella \& D'Alessandro, 1988). The sand wave system was interpreted to have been deposited in a bathyal setting by tidal currents that flowed through a narrow strait connecting the Tyrrhenian and Ionian seas (Colella \& D'Alessandro, 1988).
Gibert \& Goldring (2008) studied Bichorditesdominated ichnofabrics of the Miocene Bateig Limestone of Spain, which was deposited in pelagic sandy bottoms influenced by tidal currents and gravity flows (Gibert \& Goldring, 2007). They recognised three ichnofabrics varieties, based on the modes of preservation of the physical sedimentary structures, the sizes of the Bichordites specimens, and their modes of occurrence. The first and second varieties were characterised by sparse or crowded occurrences of this trace fossil in low-angle cross- or parallel-stratified sandstones; conversely the third variety, which is comparable to the ichnofabric treated here, was recognised from the cross-stratified sandstones of tidal sand wave deposits.

Recently, Aguirre et al. (2010) reported several ichnofabrics from the Lower Pliocene of the Guadalquivir basin, southwest Spain, recognizing a Macaronichnus ichnofabric consisting of a large morphotype of Macaronichnus (cf., Seike et al., 2011) and Bichordites. This ichnofabric was found to occur in large-scale trough cross-stratified sandstones of sand wave deposits, which are interpreted to have been deposited by wave-generated onshore currents in an inner shelf setting (Aguirre et al., 2010).

These previous studies focused primarily on sand wave systems that were driven by tidal currents, storminduced or fair-weather wave-generated currents, and/or gravity flows. However, sand wave systems can also be generated by oceanic currents, which include some of the largest current systems at the earth's surface. Such ocean current-driven sand waves are developed in various marine environments, from the deep sea floor to the shallow shelf, and represent a characteristic sedimentary environment in the marine realm (cf., Flemming, 1978; Ikehara, 1989; Ikehara \& Kinoshita, 1994; Kubo et al., 2002). However, little is known about such sand ridge systems from the 
ichnological viewpoint. Therefore, an ichnological study of the Ichijiku Formation, which is interpreted to have been deposited by the Kuroshio (or the Japan Current, one of the strongest western boundary currents), would be invaluable. To address this, the present study aims to describe the Bichordites-dominated ichnofabric of the Ichijiku sand ridge and discuss its palaeoecological implications.

\section{GEOLOGIC BACKGROUND}

The shelf sand ridge complex of the middle Pleistocene (0.7 Ma) Ichijiku Formation (Nakayama \& Masuda, 1989; Horikawa \& Ito, 2004; Sato et al., 2006) crops out in the middle part of the Boso penisula, Japan (Fig. 1a). The formation lies in the middle part of the Kazusa Group, which represents the infill of the Pliocene-Pleistocene Kazusa forearc basin that was developed in response to the westward to northwestward subduction of the Pacific plate beneath the Eurasian plate around 2.40-0.45 Ma (Ito \& Katsura, 1992, and references therein). The Kazusa Group reflects deposition in a variety of marine and paralic environments ranging from deep sea basin plains to coastal salt marshes (cf., Katsura, 1984), and exhibits overall deepening-up and successive shallowing-up facies successions that correspond to a third-order composite depositional sequence superimposed by fifth- to sixth-order high-frequency sequences (Ito \& Katsura, 1992).

The Ichijiku Formation is characterised by a convexup lenticular geometry (Fig. 1b) and is up to $400 \mathrm{~m}$ thick (Mitsunashi et al., 1961). It is encased in the muddy shelf deposits of the Awakura, Iwasaka, Kakinokidai and Chonan formations, and is erosively overlain by the incised valley fill of the Nagahama Formation (Ito, 1992). The Ichijiku Formation is interpreted to have been deposited as a sand ridge complex that was developed on a transgressive shelf during the glacioeustatic sea-level rise that occurred around $0.7 \mathrm{Ma}$, under the strong influence of the Kuroshio Current (Ito \& Horikawa, 2000; Horikawa \& Ito, 2004). The palaeodepth of the formation is thought to be $50-130$ $\mathrm{m}$, based on the palaeontological and sedimentological estimations (Nakayama \& Masuda, 1989).

\section{SEDIMENTOLOGY}

The Ichijiku Formation is composed primarily of moderately sorted coarse-grained sandstones with largescale trough cross-stratification, the set heights of which locally exceed $4 \mathrm{~m}$ (Figs 2a-2b, 3). The inclination of the
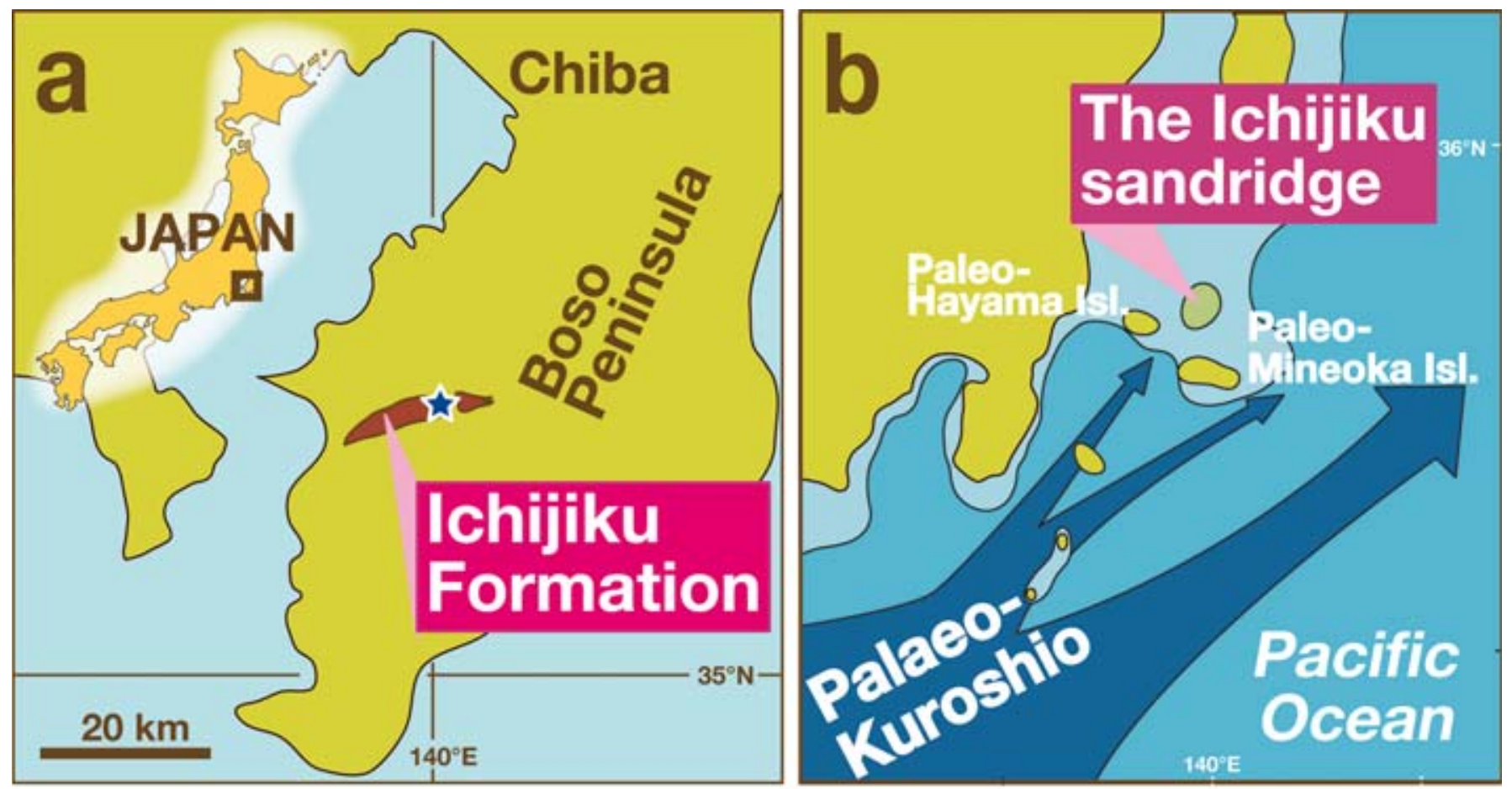

Figure 1. a) Map showing the Ichijiku Formation of the Boso peninsula, Japan, and locality of the studied outcrop (star). b) Palaeogeographical setting at the time of deposition of the Ichijiku Formation. A branch of the palaeo-Kuroshio Current flowing out from a narrow strait between the "palaeo-Hayama" and "palaeo-Mineoka" islands was the probable agent to build up the sand ridge systems (Ichijiku Sand ridge). Modified after Nakayama \& Masuda (1989). 

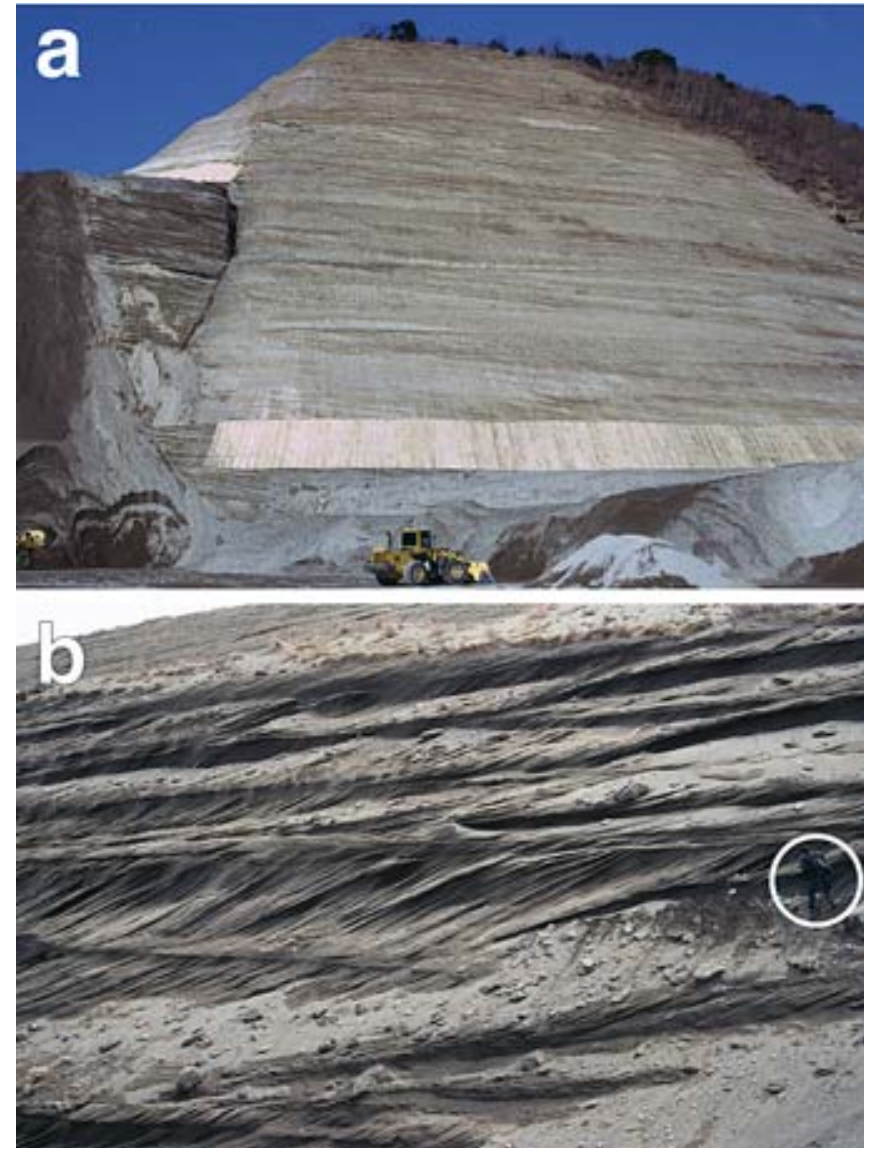

Figure 2. Outcrop photographs of the Ichijiku Formation. a) Observations were made in an active sand quarry. The wheel loader, about $3.8 \mathrm{~m}$ high, gives scale. b) The Ichijiku Formation consists primarily of largescale thorough cross-stratified sandstones. Foresets dipping to the similar directions suggest almost unidirectionally palaeocurrents of the branch of the palaeo-Kuroshio. A person encircled gives scale.

foreset commonly dips northwestward to northeastward, suggesting deposition by almost unidirectional currents. Although reactivation surfaces suggest that intermittent migration of the bedforms may occur in places, other tidal signatures (such as double mud drapes or herringbone crossstratification) are uncommon. In addition to these thickly bedded sandstones, cross-stratified or horizontally-stratified, granular very coarse- to coarse-grained sandstones or sandy granules occur in some places, exhibiting thickness of 1-5 $\mathrm{cm}$ (rarely up to $30 \mathrm{~cm}$ ) (Fig. 3). Thin beds of massive or faintly laminated mudstones are also observed (Fig. 3).

The large-scale trough cross-stratified sandstones are interpreted to have been deposited by subaqueous dunes (sand waves) developed on the sand ridge complex (Nakayama \& Masuda, 1989; Horikawa \& Ito, 2004; Sato, et al., 2006). The main depositional agent of the Ichijiku Formation has been interpreted as a branch of the Kuroshio
Current. This branch likely flowed out from a narrow seaway in between the "Palaeo-Hayama" and "PalaeoMineoka" islands (Nakayama \& Masuda, 1989) that were located southwest of the Ichijiku shelf (Fig. 1b) (Nakayama \& Masuda, 1989; Ito, 1992; Ito \& Katsura, 1992; Horikawa \& Ito, 2004; Sato et al., 2006). The flow intensity of the branch likely varied in response to the large-scale meander of the main stream (Horikawa \& Ito, 2004; Sato et al., 2006). The thinly bedded sandy conglomerates or gravelly sandstones here have been interpreted as sand ribbon deposits that were formed during stronger flow conditions, whereas the thin mudstones likely represent mud drapes deposited under slack-water conditions (cf., Nakayama \& Masuda, 1989).

Recently, Sato et al. (2006) estimated the migration rate of these sand waves based on the comparison of successive changes in the inclinations of the dune foresets with fluctuations of the modern Kuroshio Current, finding that changes in the pattern of the foreset inclinations correlated well with current fluctuations (Sato et al., 2006). Therefore, they concluded that 4.0 layers of the foreset laminae were deposited in about $12.4 \mathrm{~h}$ and estimated the average speed of the dune migration to be about $56 \mathrm{~cm} /$ day (Sato et al., 2006).

In the present study, observations were conducted in an active sand quarry located north of Ichijiku (the type locality), Kimitsu City; this location provided easily accessible outcrops (Figs 2a-2b). The Bichordites ichnofabric treated here occurs pervasively in the largescale trough cross-stratified sandstones exposed in the quarry.

\section{THE BICHORDITES ICHNOFABRIC}

Bichordites monastiriensis Plaziat \& Mahmoudi, 1988 of the Ichijiku Formation is a characteristic ichnospecies of the ichnofabric treated here and is a predominantly horizontal, meniscate burrow (about $3.5 \mathrm{~cm}$ wide and 2.5 $\mathrm{cm}$ high) with distinctly bilobate bases and tops (Figs 4, 5a-5c). A cord with a heart-shaped cross section occurs in its central part (Figs 4, 5d-5f); this central cord is typically more cemented and lighter in color than the surrounding outer portion.

The ichnofabric treated here, which is characterised by dominant $B$. monastiriensis, occurs in the largescale cross-bedded sandstones of the sand wave deposits (Fig. 6). Although the ichnofabric occurs primarily along the foreset of the sand waves, it is also seen in their bottom- and top-sets (Fig. 6). The foreset laminae are locally extensively burrowed, although the cross-bedding is more or less preserved owing to the orientation of the burrows almost parallel to the strike of the foreset. However, a few specimens cross the foreset laminae, and 


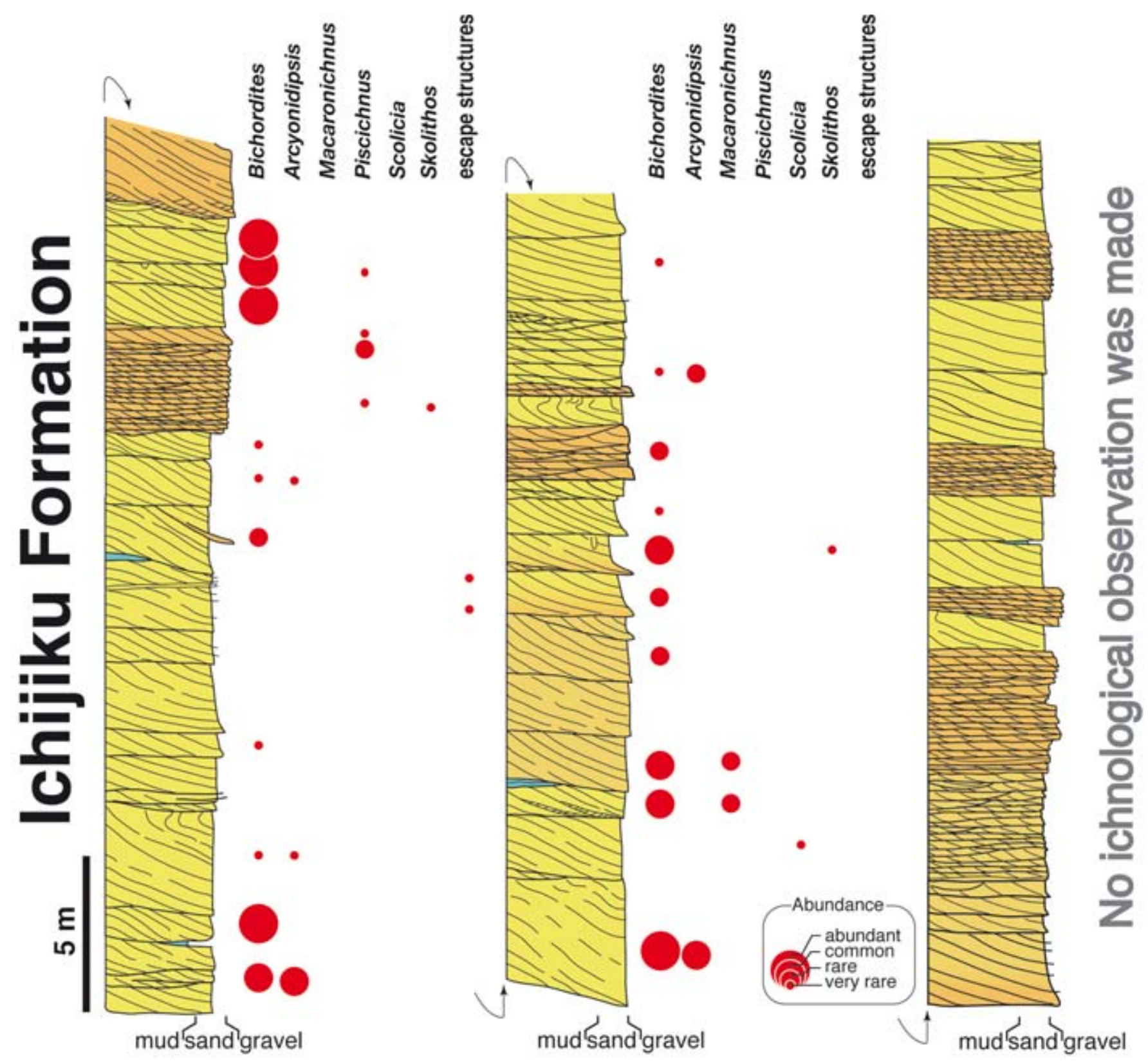

Figure 3. Geologic columns and trace fossil occurrences of the studied section, consisting of large-scale trough-cross stratified sandstones of subaqueous dune (sand wave) deposits and thinly cross-bedded sandy conglomerates of sandribbon deposits. The thin mudstones were mud drapes that were deposited under slack-water conditions.

B. monastiriensis in the foreset may be truncated by an overlying lamina (Fig. 5c). Moreover, densely occurring B. monastiriensis specimens sometimes crosscut each other (Fig. 5e). Typically, this intensely burrowed fabric is situated immediately below a reactivation surface of the foreset (Fig. 7).

Along with $B$. monastiriensis, other traces have been identified (Figs 6, 8a-8d). Alcyonidiopsis (a cylindrical branched burrow, typically $2-3 \mathrm{~mm}$ thick, filled with ovoidal faecal pellets) also occurs locally in the foreset of the dunes (Fig. 8c). Other trace fossils are rare to very rare and include large morphotypes of Macaronichnus (a burrow of the travisiid polycahetes; Seike et al., 2011) (Fig. 8f), Piscichnus (a ray feeding trace; Gregory, 1991), Scolicia (a Spatangus group burrow; Uchman \& Krenmayr, 1995) (Figs 8a-8b), Skolithos (a suspension feeder's burrow) (Fig. 8e), and unnamed escape structures (Fig. 8d). Alcyonidiopsis, the large Macaronichnus, and the escape structures commonly occur in the foreset of the dunes. Conversely, Piscichnus and Scolicia very rarely occur in the foresets and are more common in the topsets of the dune deposits (Fig. 6). 


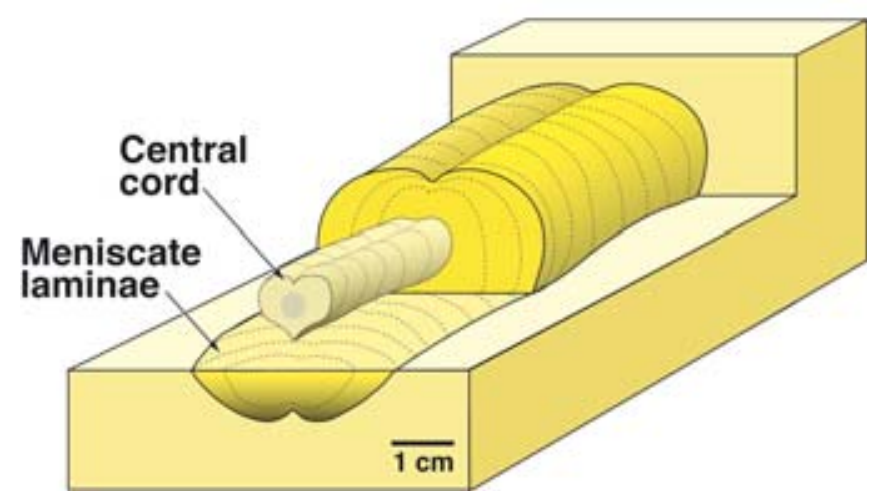

Figure 4. Schematic diagram showing Bichordites monastiriensis Plaziat \& Mahmoudi, 1988, of the Ichijiku Formation. It is a characteristic ichnospecies of the Ichijiku ichnofabric, and is a predominantly horizontal, meniscate burrow, about $3.5 \mathrm{~cm}$ wide and $2.5 \mathrm{~cm}$ high. Its base and top are distinctly bilobate. The central cord, with a heart-shaped cross section, is slightly lighter in color comparing to the outer part of the burrow. Heavy mineral grains may be concentrated in the lower margin of the burrow.

\section{DISCUSSION}

The ichnogenus Bichordites is typically interpreted as a burrow of the spatangoid that characteristically constructs a single drainage tube (e.g., Plaziat \& Mahmoudi, 1988; Uchman \& Krenmayr, 1995), with the heart-shaped central cord generally ascribed to the drainage tube (e.g., Plaziat \& Mahmoudi, 1988; Uchman \& Krenmyr, 1995; D'Alessandro \& Uchman, 2007). In fact, the spatangoid echinoids that belong to the families Echinocardiidae (e.g., Bromley \& Asgaard, 1975; Plaziat \& Mahmoudi, 1988; Bromley, 1996) or Maretiidae (e.g., Gibert \& Goldring, 2008; Bernardi et al., 2010) are generally known to construct such a single drainage burrow.

The maretiid Bichordites reported by Gibert \& Goldring (2008) can be distinguished from the Ichijiku B. monastiriensis by its large size (up to $11 \mathrm{~cm}$ in width) and relatively flattened morphology. Bernardi et al. (2010) reported another maretiid Bichordites from the Oligocene of northern Italy and assigned it to B. monastiriensis. However, the central cord of this burrow shapes like a flat tape and occupies the lower central part of the burrow (Bernardi et al., 2010). These characteristics are clearly different from those of the Ichijiku B. monastiriensis treated here.

Although no direct evidence of the tracemaker's identity has been found from the Ichijiku specimens, their morphology is very similar to that of specimens occurring in other Pleistocene sediments from the Boso peninsula (cf., Nara, 2004), some of which co-occur with intact body fossils of Echinocardium cordatum reported by Kondo \& Kamataki (2000). In modern settings, E. cordatum colonises offshore sand waves (Borsje et al., 2009), locally exhibiting dense distributions in sandy substrates. For example, up to 11 individuals have been found in a $50 \times 50 \mathrm{~cm}^{2}$ (Lohrer et al., 2005). E. cordatum is a highly active burrower and may act as the key bioturbator in some ecosystems (Lohrer et al., 2005; Borsje et al., 2009). In fact, E. cordatum is known to produce a densely burrowed sedimentary fabric (Schäfer, 1972). Therefore the most likely producer of the dense occurrence of $B$. monastiriensis in the Ichijiku Formation (Fig. 5b) is the echinocardiid spatangoid E. cordatum.

The habitats of sand wave systems are characterised by highly shifting substrates, inhibiting colonisation by benthic animals (Howard, 1978; Ekdale, 1985). In such systems, the foreset provides the most unstable substrate and is affected almost continuously by falling and avalanching of sediments during the migration of the dunes (Lindholm, 1987). For example, average sediment thickness of $56 \mathrm{~cm}$ is estimated to accumulate per day in the foreset of the Ichijiku sand waves, as noted above (Sato et al., 2006). Here, B. monastiriensis occurs in the foreset, despite the stressful environment induced by these high rates of sedimentation (cf., Kranz, 1974; Howard, 1978; Kondo, 1997; Nara, 2002; Nara et al., 2002, and references therein). Moreover, the $B$. monastiriensis specimen truncated by the foreset lamina (Fig. 5c) suggests that the burrow was formed immediately below the foreset surface; that is, the tracemaker clearly colonised the foreset.

It seems likely that $E$. cordatum would be able to cope with such a stressful environment. This is supported by the fact that E. cordatum can attain burrowing rates of 6-8 cm/h (Buchanan, 1966), which far exceeds the foreset migration rate noted above. Thus, rapid burrowers such as spatangoid echinoids were likely able to keep pace with such rapid sedimentation, as noted by Gibert \& Goldring (2008).

Previous studies investigating Bichordites have also concluded that the trace fossil commonly occurs in highly shifting substrates (e.g., Colella \& D'Alessandro, 1988; D'Alessandro et al., 2004; D'Alessandro \& Uchman, 2007; Gibert \& Goldring, 2007, 2008; Aguirre et al., 2010; Demírcan \& Uchman, 2012). For example, the type ichnospecies B. monastiriensis is considered as a characteristic trace fossil of shoreface settings (Demírcan \& Uchman, 2012), which are affected continuously by fair-weather and storm waves or currents. The maretiid Bichordites also occurs in the sediments that are interpreted to have been deposited under the continuous influence of tidal currents and associated gravity flows (Gibert \& Goldring, 2007). These studies support the present view that the $B$. monastiriensis ichnofabric may represent a stressful environment owing to shifting 

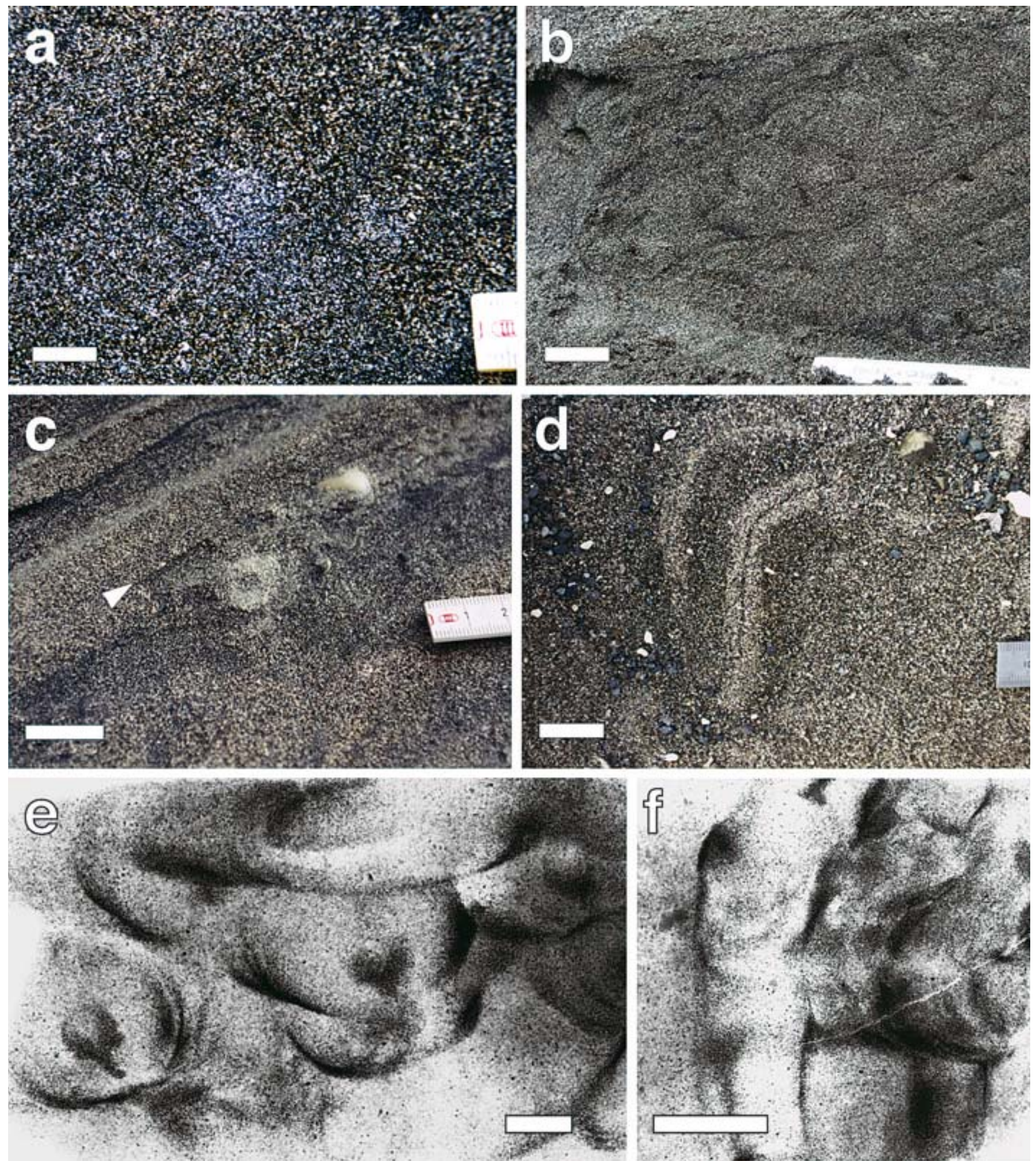

Figure 5. Bichordites monastiriensis of the Ichijiku Formation. a) Vertical view of the burrows occurring in the foreset of the sand wave deposits (scale bar: $1 \mathrm{~cm}$ ). b) The burrows may show crowded occurrence in some foresets. Vertical section. (scale bar: $3 \mathrm{~cm}$ ). c) The burrow is sometimes truncated by an overlying lamina. Vertical section. (scale bar: $2 \mathrm{~cm}$ ). d) Horizontal section of the burrows. Bilobate tops of the heart-shaped central cord is observed. (scale bar: $2 \mathrm{~cm}$ ). e) X-ray radiograph of the crowded burrows, which crosscut each other (vertical section). Note heart-shaped central cords. (scale bar: $1 \mathrm{~cm}$ ). f) $\mathrm{X}$-ray radiograph showing horizontal section of the crosscutting burrows. Note well-developed menisci. (scale bar: $2 \mathrm{~cm}$ ). 
substrates, although $B$. monastiriensis itself has also been found in the shallow marine muddy substrates that are suggestive of relatively calm environments (cf., Nara, 2004; Demírcan \& Uchman, 2012).

As noted previously, Bichordites-dominated ichnofabrics similar to that of the Ichijiku Formation have also been reported from sand wave deposits that are interpreted to have been deposited by tidal currents, onshore currents, or frequent gravity flows in various water depths (e.g., Colella \& D'Alessandro, 1988; D'Alessandro et al., 2004; Gibert \& Goldring, 2007, 2008; Aguirre et al., 2010). Therefore, the Bichordites ichnofabric can be considered to represent sand wave deposits, regardless of its water depths or driving agents. Moreover, the stressful environment induced by frequent sedimentation associated with migrating sand waves likely allowed for the colonisation of echinocardiid spatangoids.

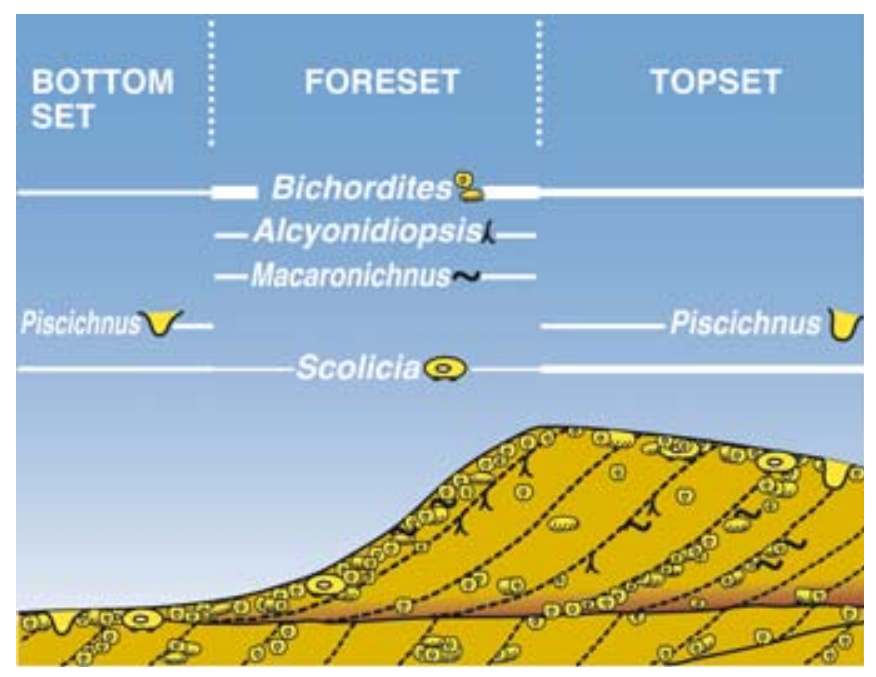

Figure 6. Schematic illustration showing trace fossils' distribution in the large-scale trough cross-bedded sandstones of the Ichijiku Formation (palaeo-Kuroshio-generated subaqueous dune deposits). Not to scale.

Some of the associated trace fossils might also have adapted to such an environment. For example, Alcyonidiopsis has been interpreted as the burrow of the spionid polychaete (Schäfer, 1972) based on the morphological similarities. The spionids are known to adjust their living position easily in response to rapid aggradation of the seafloor (Schäfer, 1972). The large morphotype of Macaronichnus has been reported from high-energy environments such as the upper shoreface, which is also characterised by shifting substrates (Nara, 1998; Seike et al., 2011). The Piscichnus producer (a nektobenthic ray) was a powerful swimmer and was

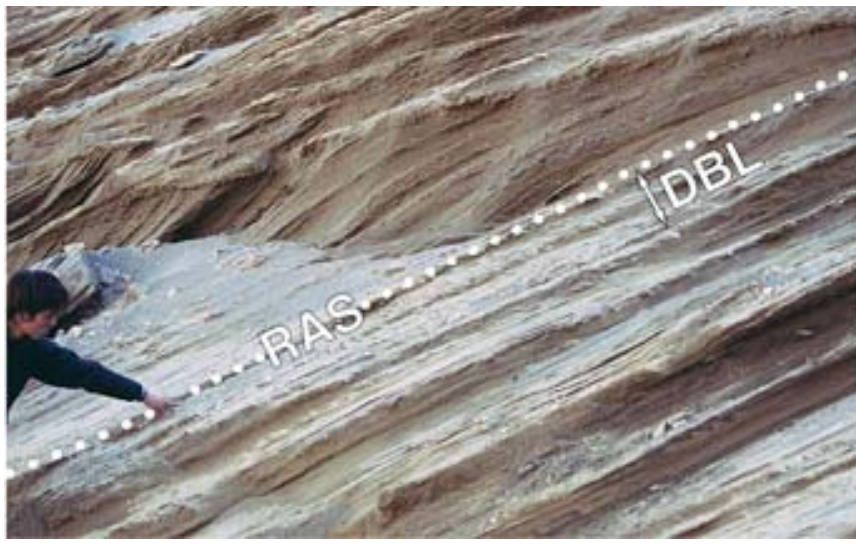

Figure 7. Densely burrowed foreset laminae (DBL) are situated immediately below the reactivation surface (RAS and dotted line). This suggests that the spatangoids' burrowing dominated physical sedimentary process during the cessation of the foreset migration. Person gives scale.

probably less affected by shifting substrates. Conversely, the very limited occurrence of Scolicia in the foresets suggests that its producer adapted less well to shifting substrates than the echinocardiids.

The first irregular echinoid and the spatangoids appeared in the Early Jurassic (Kier, 1982) and at the base of the Cretaceous (Bernadri et al., 2010), although the earliest occurrence of their possible trace fossils was in the Upper Jurassic (Tchoumatchenko \& Uchman, 2001). The Mesozoic spatangoids are typically ascribed to the ichnogenus Scolicia, which has characteristic double drainage tubes, and are present primarily in flysch facies (Plaziat \& Mahmoudi, 1988). Moreover, burrowing irregular echinoids are thought to have evolved rapidly in the Cenozoic (Goldring et al., 2004). The spatangoids that construct a single drainage tube (i.e., the echinocardiids or maretiids) appeared in the Eocene (maretiid) or Miocene (echinocardiid) (Smith \& Kroh, 2011). Fossil records of Bichordites from Miocene and younger strata are well documented (Radwanski et al., 1975; Pickerill et al., 1993; Uchman \& Krenmayr, 1995; Nara, 2004; Gibert \& Goldring, 2007, 2008; Mayoral et al., 2013), with some dating back to the Oligocene (Bernadri et al., 2010; Demírcan \& Uchman, 2012). In contrast, sand wave deposits of the Palaeozoic and Mesozoic eras are totally lacking in Bichordites-type bioturbation (cf., Dam, 1990; Pollard et al., 1993; Mángano et al., 1996; Buatois et al., 1999; Desjardins et al., 2010, 2012). Moreover, Bichordites has been omitted from previous ichnofacies models, especially those based on studies of the Mesozoic rock record (e.g., Pemberton et al., 2001; MacEarchern \& Bann, 2008; MacEarchern et al., 2009). In the early Cenozoic, the spatangoids that had previously adapted to relatively stable conditions, as suggested by the environmental distributions 

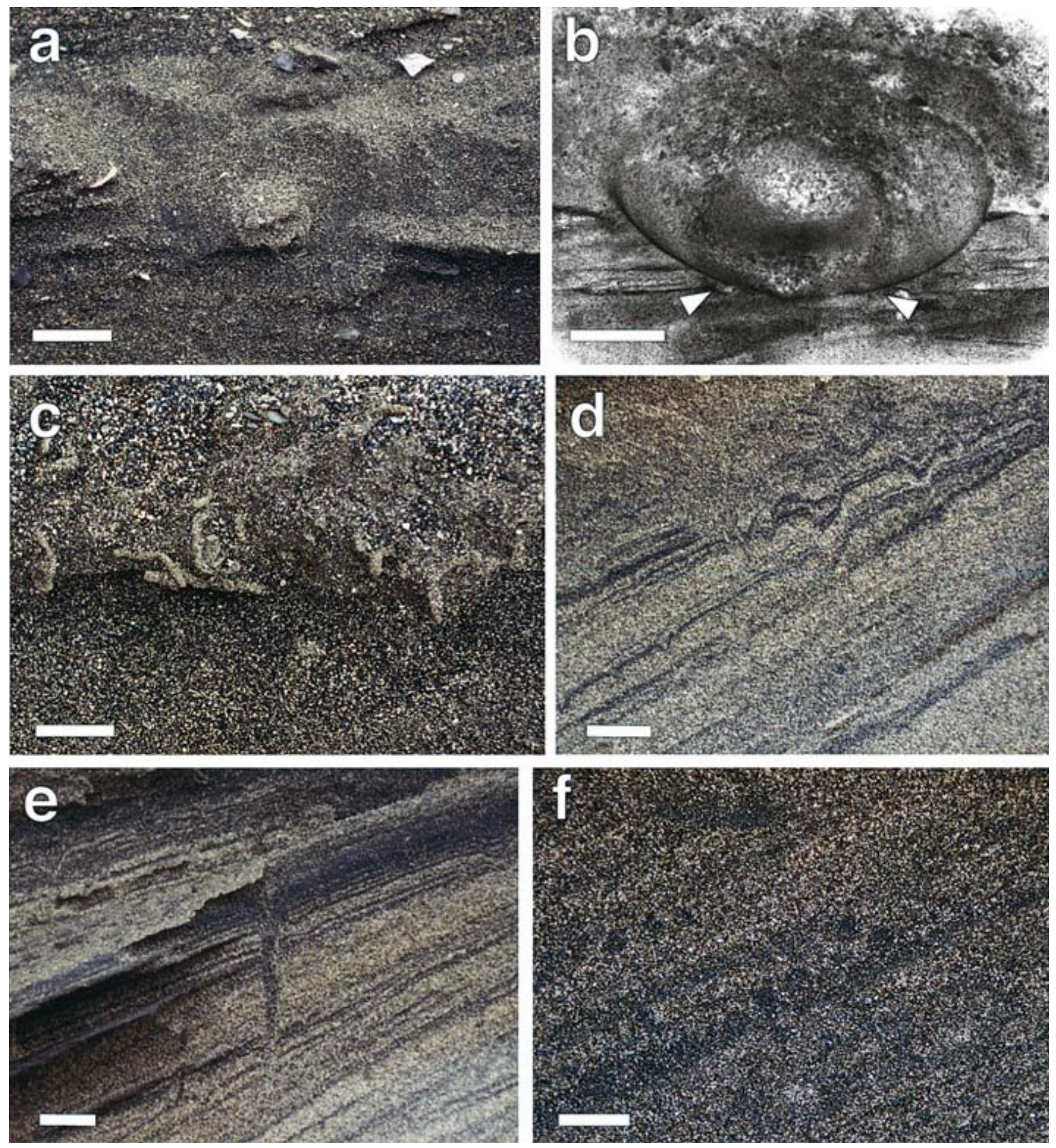

Figure 8. Photographs showing selected trace fossils co-occurring with B. monastiriensis. a) Scolicia occurring in a topset of the dune deposit. Vertical section. (scale bar: $3 \mathrm{~cm}$ ). b) X-ray radiograph of the specimen shown in a. Probable collapsed drainage tubes may be seen in the bottom (triangles). (scale bar: $2 \mathrm{~cm}$ ). c) Alcyonidiopsis isp. which is filled with ovoidal, muddy, faecal pellets. (scale bar: $2 \mathrm{~cm}$ ). d) Unnamed escape structures seen in the foreset. (scale bar: $2 \mathrm{~cm}$ ). e) Skolithos linearis penetrating probably from the topset (scale bar: $2 \mathrm{~cm}$ ). f) Macaronichnus isp. of Nara (1998) and Seike et al. (2011) in the foreset. The diameter is about $7 \mathrm{~mm}$. Although most of the previously studied Macaronichnus burrwows are filled with colorless-mineral grains, the Ichijiku specimens are commonly filled with heavy mineral-rich sand grains. (scale bar: $1 \mathrm{~cm})$. 
of Scolicia, had probably evolved into the forms producing Bichordites to cope with the unstable settings characterised by shifting substrates.

Bichordites producers (i.e., the echinocardiid and maretiid spatangoids) exhibit almost worldwide distributions (Ghiold, 1989); therefore the Bichorditesdominated ichnofabric discussed here could be considered to characterise sand wave depositional environments. Moreover, it may be used as a powerful indicator of highly shifting substrates in the Cenozoic (postOligocene?) rock record.

\section{CONCLUSIONS}

The ichnofabric dominated by the echinocardiid spatangoid burrow of Bichordites monastiriensis is found in sand wave deposits of the ocean current-generated shelf sand ridge complex of the Pleistocene Ichijiku Formation of the Boso peninsula. The sand wave environment was characterised by rapid sedimentation and highly sifting substrates, which typically prevent colonisation by benthic animals, although the highly vagile echinocardiids were likely able to colonise this environment. Previous studies have supported the view that Bichordites represents environments with relatively high energy and suggested that Bichordites appeared in the Oligocene and has flourished since the Miocene. Furthermore, the likely tracemakers now exhibit almost worldwide distribution, suggesting that the ichnofabric treated here may be used as an indicator of such environments in the Cenozoic (postOligocene?) rock record.

\section{ACKNOWLEDGEMENTS}

I dedicate this work to a congenial friend of mine, the late Dr. Jordi Maria de Gibert Atienza, who published several works on spatangoid ichnofabrics, which considerably stimulated the present study. Dr. Gibert also gave some constructive comments to this study during 11 th International Ichnofabric Workshop held in Asturias, Spain. The manuscript was improved by constructive comments from the reviewers, Prof. Luis Buatois and Dr. Zain Belaústegui. Dr. Belaústegui also helped in preparing the Spanish abstract. Mr. K. Obana helped with part of filed works. This work was partly supported by JSPS KAKENHI Grant Numbers 12740291 and 19540494. All these contributions are gratefully acknowledged.

\section{REFERENCES}

Aguirre, J., Gibert, J.M. \& Puga-Bernabéu, Á. 2010. Proximal-distal ichnofabric changes in a siliciclastic shelf, Early Pliocene, Guadalquivir Basin, southwest Spain. Palaeogeography, Palaeoclimatology, Palaeoecology, 291, 328-337.

Bernardi, M., Boschele, S., Ferretti, P. \& Avanzini, M. 2010. Echinoid burrow Bichordites monastiriensis from the Oligocene of NE Italy. Acta Palaeontologica Polonica, 55, 479-486.

Borsje, B.W., deVries, M.B., Bouma, T.J., Besio, G., Hulscher, S.J.M.H. \& Herman, P.M.J. 2009. Modeling bio-geomorphological influences for offshore sand waves. Continental Shelf Research, 29, 1289-1301.

Bromley, R.G. 1996. Trace Fossils, Biology, Taphonomy and Applications. Chapman and Hall, London.

Bromley, R.G. \& Asgaard, U. 1975. Sediment structures produced by a spatangoid echinoid: a problem of preservation. Bulletin of the Geological Society of Denmark, 24, 261-281.

Buatois, L., Mángano, M.G. \& Carr, TR. 1999. Sedimentology and ichnology of Paleozoic estuarine and shoreface reservoirs, Morrow Sandstone, Lower Pennsylvanian of southwest Kansas, USA. Kansas Geological Survey Bulletin, 243, 1-35.

Buchanan, J.B. 1966. The biology of Echinocardium cordatum [Echinodermata: Spatangoidea] from different habitats. Journal of the Marine Biological Association of the United Kingdom, 46, 97-114.

Colella, A. \& D'Alessandro, A. 1988. Sand waves, Echinocardium traces and their bathyal depositional setting (Monte Torre Palaeostrait, Plio-Pleistocene, southern Italy). Sedimentology, 35, 219-237.

D'Alessandro, A. \& Massari, F. 1997. Pliocene and Pleistocene depositional environments in the Pesculuse area (Salento, Italy). Rivista Italiana di Paleontologia e Stratigrafia, 103, 221-258.

D'Alessandro, A. \& Uchman, A. 2007. Bichordites and Bichordites-Rosselia ichnoassemblages from the lower Pleistocene Tursi Sandstone (Southern Italy). In: Sediment-organism interactions: A multifaceted ichnology (eds Bromley, R.G., Buatois, L.A., Mángano, G., Genise, J.F. \& Melchor, R.N.). SEPM Special Publication, 88, Tulsa, 213-221.

D’Alessandro, A., Massari, F., Davaud, E. \& Ghibaud, G. 2004. Pliocene-Pleistocene sequences bounded by subaerial unconformities within foramol ramp calcarenites and mixed deposits (Salento, SE Italy). Sedimentary Geology, 166, 89-144.

Dam, G. 1990. Palaeoenvironmental significance of trace fossils from the shallow marine Lower Jurassic Neill Klinter Formation, East Greenland. Palaeogeography, Palaeoclimatology, Palaeoecology, 79, 221-248.

Demírcan, H. \& Uchman, A. 2012. The miniature echinoid trace fossil Bichordites kuzunensis isp. nov. from early Oligocene prodelta sediments of the Mezardere Formation, 
Gökçeada Island, NW Turkey. Acta Geologica Polonica, 62, 205-215.

Desjardins, P., Mángano, M.G., Buatois, L. \& Pratt, B. 2010. Skolithos pipe rock and associated ichnofabrics from the southern Rocky Mountains, Canada: colonization trends and environmental controls in an early Cambrian sandsheet complex. Lethaia, 43, 507-528.

Desjardins, P., Buatois, L., Pratt, B. \& Mángano, M.G. 2012. Sedimentological-ichnological model for tide-dominated shelf sandbodies: Lower Cambrian Gog Group of western Canada. Sedimentology, 59, 1452-1477.

Ekdale, A.A. 1985. Paleoecology of the marine endobenthos. Palaeogeography, Palaeoclimatology, Palaeoecology, 50, 63-81.

Flemming, B.W. 1978. Underwater sand dunes along the southeast African continental margin-Observations and implications. Marine Geology, 26, 177-198.

Ghiold, J. 1989. Species distributions of irregular echinoids. Biological Oceanography, 6, 79-162.

Gibert, J.M. de \& Goldring, R. 2007. An ichnofabric approach to the depositional interpretation of the intensely burrowed Bateig Limestone, Miocene, SE Spain. Sedimentary Geology, 194, 1-16.

Gibert, J.M. de \& Goldring, R. 2008. Spatangoid-produced ichnofabrics (Bateig Limestone, Miocene Spain) and the preservation of spatangoid trace fossils. Palaeogeography, Palaeoclimatology, Palaeoecology, 270, 299-310.

Goldring, R., Cadeé, G.C., D’Alessandro, A., Gibert, J.M., Jenkins, R. \& Pollard, J. 2004. Climatic control of marine trace fossil distribution. Geological Society London, Special Publications, 228, 77-92.

Gregory, M. 1991. New trace fossils from the Miocene of Northland, New Zealand: Rorschachichnus amoeba and Piscichnus waitemata. Ichnos, 1, 195-205.

Horikawa, K. \& Ito, M. 2004. Long-term ENSO-like events represented in the middle Pleistocene shelf successions, Boso Penisula, Japan. Palaeogeography, Palaeoclimatology, Palaeoecology, 203, 239-251.

Howard, J.D. 1978. Sedimentology and trace fossils. In: Trace Fossil Concepts (ed. Basan, P.). SEPM Short Course, 5, $11-42$.

Ikehara, K. 1989. The Kuroshio-generated bedform system in the Osumi Strait, southern Kyushu, Japan. In: Sedimentary Facies in the Active Plate Margin (eds Taira, A. \& Masuda, F.). TERRAPUB, Tokyo, 261-273.

Ikehara, K. \& Kinoshita, Y. 1994. Distribution and origin of subaqueous dunes on the shelf of Japan. Marine Geology, 120, 261-273.

Ito, M. 1992. High-frequency depositional sequences of the upper part of the Kazusa Group, a middle Pleistocene forearc basin fill in Boso Penisula, Japan. Sedimentary Geology, 76, 155-175.

Ito, M. \& Katsura, Y. 1992. Inferred glacio-eustatic control for high-frequency depositional sequences of the PlioPleistocene Kazusa Group, a forearc basin fill in Boso Penisula, Japan. Sedimentary Geology, 80, 67-75.

Ito, M. \& Horikawa, K. 2000. Millennial- to decadal-scale fluctuation in the paleo-Kuroshio Current documented in the Middle Pleistocene shelf succession on the Boso Penisula, Japan. Sedimentary Geology, 137, 1-8.

Katsura, Y. 1984. Depositional environments of the PlioPleistocene Kazusa Group, Boso Penisula, Japan. Scientific Reports of the Institute of Geoscience University of Tsukuba, C5, 69-104.

Kier, P.M. 1982. Rapid evolution in echinoids. Palaeontology, 25, 1-9.

Kondo, Y. 1997. Inferred bivalve response to rapid burial in a Pleistocene shallow marine deposit from New Zealand. Palaeogeography, Palaeoclimatology, Palaeoecology, 128, 87-100.

Kondo, Y. \& Kamataki, T. 2000. Method of field paleontology: Examples of bivalves in the Pleistocene Paleo-Tokyo Bay deposit. In: Dynamic Paleoecology, Interactions Between Paleoenvironments and Fossil Benthic Communities (ed. Nara, M.). Topics in Paleontology, 1, The Palaeontological Society of Japan, Tokyo, 37-67.

Kranz, P.M. 1974. The anastrophic burial of bivalves and its paleoecological significance. Journal of Geology, 82, 237-265.

Kubo, Y., Soh, W., Machiyama, H. \& Toliyama, H. 2002. Bedforms produced by the Kuroshio Current over the Izu Ridge: Side-scan sonar surveys around Kozu Sima, Niijima and Miyake Sima islands, central Japan. Journal of the Geological Society of Japan, 108, 103-113.

Lindholm, R. 1987. A Practical Approach to Sedimentology. Unwin Hyman, London.

Lohrer, A.M., Thrush, S.F., Hunt, L., Hancock, N. \& Lundquist, C. 2005. Rapid reworking of subtidal sediments by burrowing spatangoid urchins. Journal of Experimental Marine Biology and Ecology, 321, 155-169.

MacEachern, J.A. \& Bann, K.L. 2008. The role of ichnology in refining shallow marine facies models. In: Recent Advances in Models of Siliciclastic Shallow-Marine Stratigraphy (eds Hampson, G.J., Steel, R.J., Burgess, P.M. \& Dalrymple, R.W.). SEPM Special Publication, 90, 73-116.

MacEachern, J.A., Pemberton, S.G., Bann, K.L. \& Gingras, M.K. 2009. Departures from the archetypal ichnofacies: Effective recognition of physic-chemical stresses in the rock record. In: Applied Ichnology (eds MacEachern, J.A., Bann, K.L., Gingras, M.K. \& Pemberton, S.G.). SEPM Short Course, 57, 65-93.

Mángano, M.G., Buatois, L.A. \& Aceñolaza, G.F. 1996. Trace fossils and sedimentary facies from a Late Cambrian-Early Ordovician tide-dominated shelf (Santa Rosita Formation, northwest Argentina): Implications for ichnofacies models of shallow marine successions. Ichnos, 5, 53-88.

Mayoral, E., Ledesma-Vazquez, J., Baarli, B.G., Santos, A., Ramalho, R., Cachão, M., da Silva, C.M. \& Johnson, M.E. 2013. Ichnology in oceanic islands; case studies from the Cape Verde Archipelago. Palaeogeography, Palaeoclimatology, Palaeoecology, 381-382, 47-66.

Mitsunashi, T., Yazaki, K., Kageyama, K., Shimada, T., Ono, E., Yasukuni, N., Marino, T., Shimada, Y., Fujiwara, K. \& Kamada, S. 1961. Geological maps of oil and gas fields 
of Japan 4, Futtsu-Otaki (scale 1:50000). Geological Survey of Japan.

Nakayama, N. \& Masuda, F. 1989. Ocean current-controlled sedimentary facies of the Pleistocene Ichijiku Formation, Kazusa Group, Boso Penisula, Japan. In: Sedimentary Facies in the Active Plate Margin (eds Taira, A. \& Masuda, F.). TERRAPUB, Tokyo, 275-293.

Nara, M. 1998. Depositional environments and sequence stratigraphic analysis of the middle Pleistocene Kongochi Formation. Journal of Geography, 107, 77-91.

Nara, M. 2002. Crowded Rosselia socialis in Pleistocene inner shelf deposits: Benthic paleoecology during rapid sea-level rise. Palaios, 17, 268-276.

Nara, M. 2004. Trace fossil Bichordites monastiriensis in Pleistocene shallow marine deposits of the Boso Penisula, central Japan, and its paleoenvironmental significance. Journal of the Geological Society of Japan, 110, 19-20.

Nara, M., Watanabe, H., Inouchi, Y., Kutsuna, S. \& Yanagisawa, A. 2002. Tolerance of the lancelet Branchiostoma belcheri to rapid burial with coarse- and fine-grained clastics. Japanese Journal of Benthology, 57, 97-105.

Pemberton, G.S., Spila, M., Pulham, A.J., Saunders, T., MacEachern, J.A., Robbins, D. \& Sinclair, I.K. 2001. Ichnology and sedimentology of shallow to marginal marine systems: Ben Nevis \& Avalon Reservoirs, Jeanne d'Arc Basin. Short Course Notes, 15. Geological Association of Canada.

Pickerill, R.K., Donovan, S.K., Dixon, H.L. \& Doyle, E.N. 1993. Bichordites monastiriensis from the Pleistocene of southeast Jamaica. Ichnos, 2, 225-230.

Plaziat, J.-C. \& Mahmoudi, M. 1988. Trace fossils attributed to burrowing echinoids: a revision including new ichnogenus and ichnospecies. Geobios, 21, 209-233.
Pollard, J.E, Goldring, R. \& Buck, S.G. 1993. Ichnofabrics containing Ophiomorpha: significance in shallow-water facies interpretation. Journal of the Geological Society of London, 150, 149-164.

Radwanski, A., Friis, H. \& Larsen, G. 1975. The Miocene Hagenør-Børup sequence at Lillebælt (Denmark): its biogenic structures and depositional environment. Bulletin of Geological Society of Denmark, 24, 229-260.

Sato, T., Masuda, F. \& Nishio, T. 2006. Estimation of the depositional time by comparison of foreset lamina crossstratification angles and ocean current fluctuations: The Pleistocene Ichijiku Formation, Kazusa Group. Marine Geology, 235, 241-245.

Schäfer, W. 1972. Ecology and Palaeoecology of Marine Environments. The University of Chicago Press, Chicago.

Seike, K., Yanagishima, S.-I., Nara, M. \& Sasaki, T. 2011. Large Macaronichnus in modern shoreface sediments: Identification of the producer, the mode of formation, and paleoenvironmental implications. Palaeogeography, Palaeoclimatology, Palaeoecology, 311, 224-229.

Smith, A.B. \& Kroh, A. 2011. The Echinoid Directory. World Wide Web electronic publication, http://www.nhm.ac.uk/ research-curation/projects/echinoid-directory [accessed May 6 2013].

Tchoumatchenco, P. \& Uchman, A. 2001. The oldest deep-sea Ophiomorpha and Scolicia and associated trace fossils from the Upper Jurassic-Lower Cretaceous deep-water turbidite deposits of SW Bulgaria. Palaeogeography, Palaeoclimatology, Palaeoecology, 169, 85-99.

Uchman, A. \& Krenmayr, H.G., 1995. Trace fossils from Lower Miocene (Ottnangian) molasse deposits of Upper Austria. Paläontologische Zeitschrift, 69, 503-524. 